\title{
Physical Chemical Technique
}

National Cancer Institute

\section{Source}

National Cancer Institute. Physical Chemical Technique. NCI Thesaurus. Code C19236.

Techniques based on the principles of physical and chemical science, for the study of biological problems. 